Parasitology

\title{
Evaluation of serological and molecular tests used to identify Toxoplasma gondii infection in pregnant women attended in a public health service in São Paulo state, Brazil
}

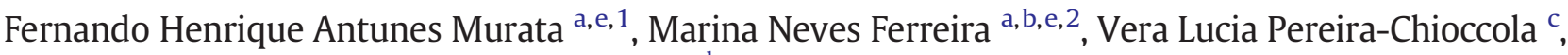 \\ Lígia Cosentino Junqueira Franco Spegiorin ${ }^{\mathrm{a}, \mathrm{d}, \mathrm{e}}$, Cristina da Silva Meira-Strejevitch ${ }^{\mathrm{c}}$, Ricardo Gava ${ }^{\mathrm{c}}$, \\ FAMERP Toxoplasma Research Group ${ }^{\mathrm{e}, 3}$, Aparecida Perpétuo Silveira-Carvalho ${ }^{\mathrm{a}, \mathrm{e}}$, \\ Luiz Carlos de Mattos ${ }^{\mathrm{a}, \mathrm{e}}$, Cinara Cássia Brandão de Mattos ${ }^{\mathrm{a}, \mathrm{e}, *}$ \\ a Faculdade de Medicina de São José do Rio Preto - FAMERP, São José do Rio Preto, São Paulo, Brazil \\ b Instituto de Biociências Letras e Ciência Exatas, Universidade Estadual Paulista "Júlio de Mesquista Filho" - IBILCE-UNESP, São José do Rio Preto, São Paulo, Brazil \\ c Laboratório de Biologia Molecular de Parasitas e Fungos do Centro de Parasitologia e Micologia, Instituto Adolfo Lutz - IAL, São Paulo, São Paulo, Brazil \\ ' Hospital da Criança e Maternidade, São José do Rio Preto, São Paulo, Brazil \\ e FAMERP Toxoplasma Research Group, São José do Rio Preto, São Paulo, Brazil
}

\section{A R T I C L E I N F O}

\section{Article history:}

Received 16 December 2016

Received in revised form 7 June 2017

Accepted 9 June 2017

Available online 17 June 2017

\section{Keywords:}

Toxoplasma gondii

Toxoplasmosis

Molecular diagnosis

Serology

Polymerase chain reaction

Gestational toxoplasmosis

\begin{abstract}
A B S T R A C T
Toxoplasmosis during pregnancy can have severe consequences. The use of sensitive and specific serological and molecular methods is extremely important for the correct diagnosis of the disease. We compared the ELISA and ELFA serological methods, conventional PCR (CPCR), Nested PCR and quantitative PCR (qPCR) in the diagnosis of Toxoplasma gondii infection in pregnant women without clinical suspicion of toxoplasmosis (G1 =94) and with clinical suspicion of toxoplasmosis $(G 2=53)$. The results were compared using the Kappa index, and the sensitivity, specificity, positive predictive value and negative predictive value were calculated. The results of the serological methods showed concordance between the ELISA and ELFA methods even though ELFA identified more positive cases than ELISA. Molecular methods were discrepant with CPCR using B22/23 primers having greater sensitivity and lower specificity compared to the other molecular methods.
\end{abstract}

(c) 2017 Elsevier Inc. All rights reserved.

\section{Introduction}

Toxoplasmosis, an infection caused by the obligate intracellular parasite Toxoplasma gondii, affects mammals and birds worldwide (Dubey, 2008; Robert-Gangneux and Dardé, 2012). In humans, the

\footnotetext{
* Corresponding author. Tel.: +55-17-3201-5897.

E-mail addresses: cinara.brandao@famerp.br, cinara.brandao@live.com (C.C. Brandão de Mattos).

1 Current address: Animal Parasitic Diseases Laboratory, Beltsville Agricultural Research Center, Agricultural Research Service, United States Department of Agriculture, Beltsville, MD, 20705-2350, USA.

2 Department of Preventive Veterinary Medicine and Animal Health, Faculty of Veterinary Medicine (FMVZ), University of São Paulo (USP).

${ }^{3}$ FAMERP Toxoplasma Research Group list of Authors: Fernando Henrique Antunes Murata; Marina Neves Ferreira; Aparecida Perpétuo Silveira Carvalho; Lígia Cosentino Junqueira Franco Spegiorin; Lilian Castiglioni; Fabiana Nakashima; Marina Bragheto de Oliveira; Fausto da Silva Gonçalves; Cristiane Moraes Dias; Natália Sayoun; Gabriela Soria Santos; Denise Cristina Mós Vaz-Oliani; Eloisa Aparecida Galão; Antonio Hélio Oliani; Luiz Carlos de Mattos; Cinara Cássia Brandão de Mattos.
}

disease can be severe especially during pregnancy, as the parasite can cross the placental barrier and infect the fetus with serious and even fatal consequences (Robert-Gangneux and Dardé, 2012).

The prevalence of gestational toxoplasmosis is high in many regions of Brazil (Câmara et al., 2015; Gontijo et al., 2015; Lopes-Mori et al., 2013; Moura et al., 2013; Porto et al., 2008; Rebouças et al., 2011; Spalding et al., 2005; Sroka et al., 2010) including the northwestern region of São Paulo State (64.4\% - Mattos et al., 2011a) (Fig. 1). Early diagnosis and anti-parasite treatment can reduce the severity of the fetal disease, but complications, such as microcephaly, hydrocephalus, cerebral calcifications, retinocoroidites, and mental retardation, can occur if cases remain untreated (Bittencourt et al., 2012; Fochi et al., 2015; McLeod et al., 2012, 2014; Rodrigues et al., 2009; Sroka et al., 2010).

The diagnosis of toxoplasmosis is challenging because the clinical manifestations are often nonspecific. Thus, the use of sensitive serological and molecular tests is extremely important to identify the disease early (Bichara et al., 2012; Lago et al., 2014; McLeod, 2014; Robert-Gangneux and Dardé, 2012). The aim of this study was to compare the serological and molecular methods used to diagnose 


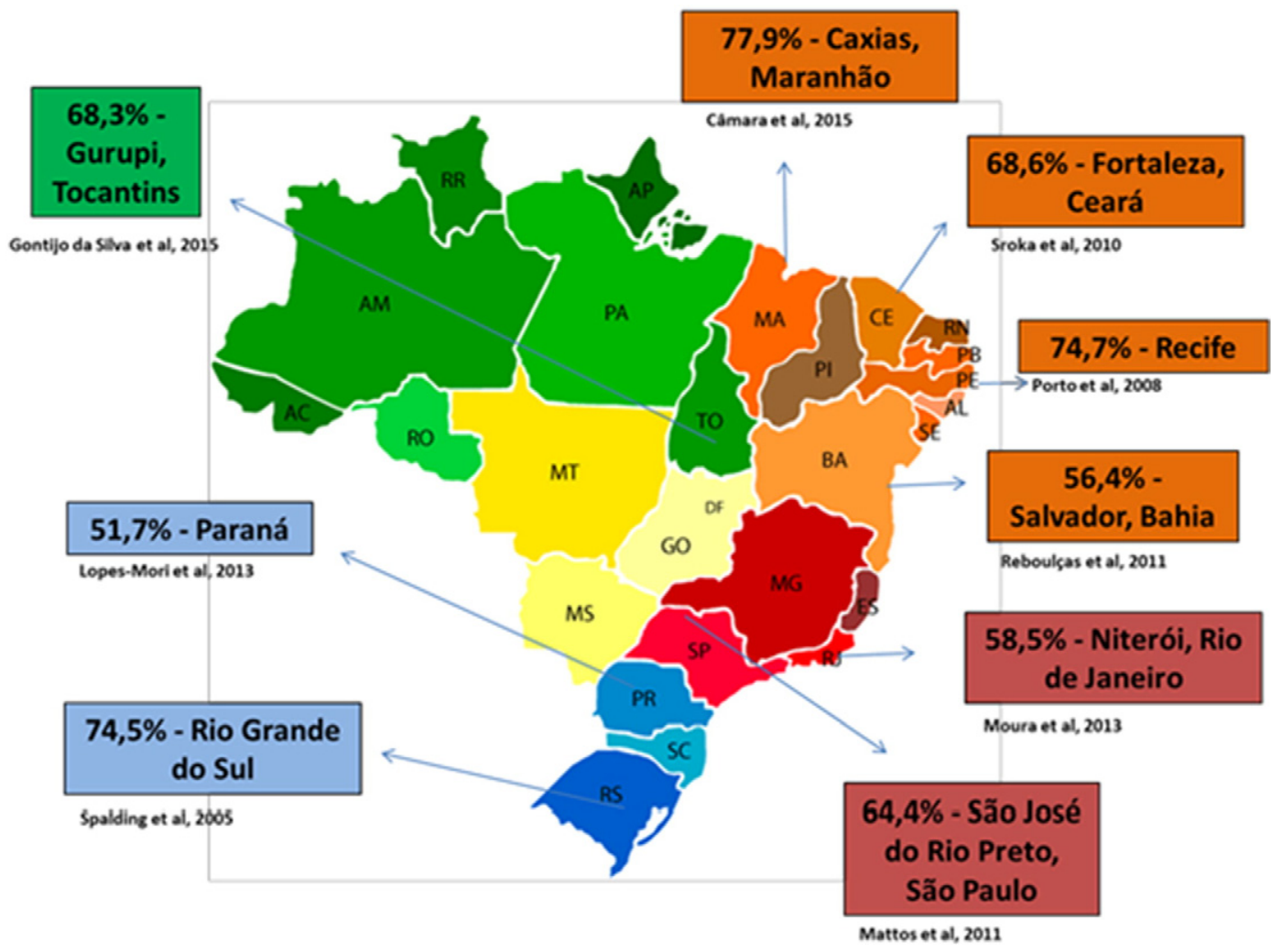

Fig. 1. Seroprevalence of $T$. gondii infection in different regions of Brazil.

toxoplasmosis in pregnant women treated at a teaching hospital in the northwestern region of São Paulo State.

\section{Material and methods}

\subsection{Ethics statement}

This study was approved by the Ethics Committee of the Medicine School in São José do Rio Preto (FAMERP-CAAE 32259714.8.0000.5415).

\subsection{Patients and clinical samples}

This is a retrospective study that evaluated pregnant women treated at the High-risk Antenatal Care and Fetal Medicine Outpatient Clinic of the Fundação Faculdade Regional de Medicina, Hospital de Base (FUNFARME), São José do Rio Preto, São Paulo State, Brazil. The pregnant women were characterized in 2 groups: G1 - Pregnant women without clinical suspicion of toxoplasmosis, who had been referred to the clinic due to other complications ( $n=94)$ and G2 - high-risk pregnant women with suspicion of toxoplasmosis and/or positive for IgM antiT. gondii antibodies at some time during pregnancy $(n=53)$.

Peripheral blood was collected from all subjects in a dry tube for serological analysis and in a tube with ethylenediaminetetraacetic acid (EDTA) for DNA extraction and molecular tests. Serological and molecular analyses were performed in the Immunogenetics Laboratory, Molecular Biology Department, FAMERP, São José do Rio Preto, São Paulo, Brazil. Of the 53 pregnant women in G2, 50 were also submitted to amniocentesis to investigate T. gondii in amniotic fluid. Amniotic fluid was sent to the reference laboratory of the São Paulo State Health Department (Dr. Vera Pereira-Chioccola) for conventional polymerase chain reaction (CPCR). All pregnant women are routinely screened in the High-risk Antenatal Care and Fetal Medicine Outpatient Clinic for TORSCH (Toxoplasmosis, Rubella, Syphilis, Cytomegalovirus, Hepatitis and HIV) (Gonçalves et al., 2010).

\subsection{Serological diagnosis}

The presence of anti-T. gondii was confirmed by enzyme linked immunosorbent assay (ELISA, DiaSorin, Italy) using the ETI-TOXOK-A reverse plus kit for IgA, ETI-TOXOK-M reverse plus kit for IgM and ETI-TOXOK-G plus kit for IgG, and enzyme linked fluorescent assay (ELFA, Biomerieux, France) using the Vidas®Toxo IgM kit for IgM, Vidas®Toxo IgG II kit for $\operatorname{Ig} G$ and Vidas ${ }^{\circledR} T o x o$ IgG avidity kit for IgG avidity. The detection of IgA and IgM antibodies was performed by capture ELISA. All samples that were positive for IgG and IgM anti-T. gondii antibodies by ELFA were also assayed using the ELFA IgG avidity test. Low-avidity antibodies $(<25 \%)$ are indicative of recent infection. ELFA was performed in automated equipment (Mini Vidas, Biomerieux, France). Both tests were performed according to manufacturer's instructions. Samples were considered positive for IgG antibodies by ELISA when the concentration was $>15 \mathrm{IU} / \mathrm{mL}$ and negative when the IgG concentration was $\leq 15 \mathrm{IU} / \mathrm{mL}$. Results were considered positive for IgA antibodies by ELISA when the IgA concentration was $>5 \mathrm{AU} / \mathrm{mL}$, and negative when the concentration was $\leq 5 \mathrm{AU} / \mathrm{mL}$. For the IgM ELISA test, the absorbance values of the samples were compared with the average cut-off point; samples were considered positive when the absorbance values were higher than or equal to the cut-off point with the remaining samples being considered negative. By ELFA, samples were considered positive for $\operatorname{IgG}$ antibodies when the value was $\geq 8 \mathrm{IU} / \mathrm{mL}$, indeterminate from $\geq 4$ to $\leq 8 \mathrm{IU} / \mathrm{mL}$ and negative when $<4 \mathrm{IU} / \mathrm{mL}$. For IgM antibodies, ELFA results were positive when the reagent index was $\geq 0.65 \mathrm{IU} / \mathrm{mL}$, indeterminate from $<0.65$ to $\geq 0.55 \mathrm{IU} / \mathrm{mL}$ and negative $<0.55 \mathrm{IU} / \mathrm{mL}$. Results demonstrated low $\operatorname{IgG}$ avidity when the $\operatorname{IgG}$ antibody concentration was $<0.200$, intermediate avidity was between 0.200 and 0.300 and high avidity when the IgG antibody concentration was $\geq 0.300$.

\subsection{Molecular diagnosis}

\subsubsection{Genomic DNA extraction}

The genomic DNA was extracted from $5 \mathrm{~mL}$ of peripheral blood collected in EDTA using a commercial kit (Qiamp DNA blood mini kit, 
Qiagen, Germany) according to the protocol described by Mattos et al. (2011b). The extracted DNA was stored in a freezer at $-20^{\circ} \mathrm{C}$ until polymerase chain reaction (PCR).

\subsubsection{Identification of the Toxoplasma gondii B1 gene}

2.4.2.1. Conventional polymerase chain reaction ( $C P C R)$. $C P C R$ was performed to identify $T$. gondii DNA in blood samples. Two CPCR reactions were performed, one with the JW62/63 primer pair and the other with the B22/23 primer pair. The B22 (sense: 5'AACGGGCGAGTAGCACCTGAGGAGA-3') and B23 primers (anti-sense: 5'-TGGGTCTACGTCGATGGCATGACAACT-3') amplify a 115-base-pair sequence of a specific repetitive region of the $B 1$ gene (accession numbers: B1 gene T. gondii = GenBank: KR559682.1) (Burg et al., 1989; Colombo et al., 2005). The PCR mixture was prepared using $8.5 \mu \mathrm{L}$ of nuclease-free water (Promega, USA); $12.5 \mu \mathrm{L}$ of GoTaq Green Master Mix (Promega, USA) and $1.0 \mu \mathrm{L}$ of each of the B22 and B23 primers (25 pmol each - IDT, USA). DNA from patients and controls $(5 \mu \mathrm{L}$ in [100 ng/ $\mu \mathrm{L}$ ]) were added to the PCR mixture in a final volume of $25 \mu \mathrm{L}$. The PCR cycling conditions consisted of an initial denaturation step at $95{ }^{\circ} \mathrm{C}$ for $5 \mathrm{~min}, 35$ amplification cycles of $45 \mathrm{~s}$ at $95{ }^{\circ} \mathrm{C}, 45 \mathrm{~s}$ at $62{ }^{\circ} \mathrm{C}$ and $45 \mathrm{~s}$ at $72{ }^{\circ} \mathrm{C}$ with a final extension of $5 \mathrm{~min}$ at $72{ }^{\circ} \mathrm{C}$ in a thermocycler (Verity, Applied Biosystems, USA). The PCR products were electrophoresed in $1.5 \%$ agarose gel using SYBR Safe stain (Invitrogen, USA).

2.4.2.2. Nested PCR. CPCR was performed using the JW62 (antisense: 5'TTCTCGCCTCATTTCTGGGTCTAC-3') and JW63 primer pair (Sense: 5'GCACCTTTCGGACCTCAACAACCG-3'), which amplifies a fragment of 286 base pairs of the T. gondii B1 gene. The PCR mixture was prepared using $6.5 \mu \mathrm{L}$ nuclease-free water (Promega, USA), $12.5 \mu \mathrm{L}$ of GoTaq Green Master Mix (Promega, USA) and $0.5 \mu \mathrm{L}$ of each of the JW62 and JW63 primers ( $10 \mu \mathrm{M}$ each primer - IDT, USA). DNA from patients and controls $(5 \mu \mathrm{L}$ in $[100 \mathrm{ng} / \mu \mathrm{L}])$ were added to the PCR mixture in a final volume of $25 \mu \mathrm{L}$. The PCR cycling conditions consisted of an initial denaturation step at $95^{\circ} \mathrm{C}$ for $5 \mathrm{~min}, 40$ amplification cycles of $45 \mathrm{~s}$ at $95{ }^{\circ} \mathrm{C}$, $45 \mathrm{~s}$ at $55^{\circ} \mathrm{C}$ and $45 \mathrm{~s}$ at $72{ }^{\circ} \mathrm{C}$ with a final extension of $5 \mathrm{~min}$ at $72^{\circ} \mathrm{C}$ in a thermocycler (Verity, Applied Biosystems, USA). The PCR products were electrophoresed in $1.5 \%$ agarose gel using SYBR Safe stain (Invitrogen, USA).

The amplified product was subjected to a second PCR (Nested PCR) using the B22/23 primer pair following the protocol published by Okay et al. (2009) with modifications. The PCR mixture was prepared for the second reaction using $6.5 \mu \mathrm{L}$ nuclease-free water (Promega, USA), $12.5 \mu \mathrm{L}$ of GoTaq Green Master Mix (Promega, USA) and $0.5 \mu \mathrm{L}$ of each of the B22 and B23 primers (25 pmol of each primer - IDT, USA). Five microliters from the first amplification reaction using the JW62/63 primer pair were added. The PCR cycling conditions consisted of an initial denaturation step at $95^{\circ} \mathrm{C}$ for $5 \mathrm{~min}, 25$ amplification cycles of $45 \mathrm{~s}$ at $95{ }^{\circ} \mathrm{C}, 45 \mathrm{~s}$ at $62{ }^{\circ} \mathrm{C}$ and $45 \mathrm{~s}$ at $72{ }^{\circ} \mathrm{C}$ with a final extension of 5 min at $72{ }^{\circ} \mathrm{C}$ in a thermocycler (Verity, Applied Biosystems, USA). The PCR products were electrophoresed in $1.5 \%$ agarose gel using SYBR Safe stain (Invitrogen, USA).

2.4.2.3. Real-time PCR ( $q P C R$ ). Genomic DNA was also subjected to realtime PCR (qPCR) to investigate the $B 1$ gene. The primers used in the real-time PCR reactions were forward (5'-TGCATCCAACGAGTTTATAA$3^{\prime}$ ), reverse (5'-GGCATTCCTCGTTGAAGATT-3') and TaqMan (FAMATTGCAATAATCTATCCCCATCACGATGCATAC-BBQ). Real-time PCR was performed in a Step One Plus system (Applied Biosystems, USA) using the following mixture: $4.5 \mu \mathrm{L}$ nuclease-free water, $10.0 \mu \mathrm{L} 2 \times$ QuantiTect Probe PCR Master Mix, $0.5 \mu \mathrm{L}$ of PrimeTime kit ( $500 \mathrm{nM}$ of each primer and $250 \mathrm{nM}$ of probe) (Qiagen, Germany). DNA from patients and controls $(5 \mu \mathrm{L}$ in $[100 \mathrm{ng} / \mu \mathrm{L}])$ were added to the PCR mixture in a final volume of $25 \mu \mathrm{L}$. The PCR cycling conditions used for qPCR consisted of an initial denaturation step at $50{ }^{\circ} \mathrm{C}$ for $2 \mathrm{~min}$, once at $95{ }^{\circ} \mathrm{C}$ for $15 \mathrm{~min}, 40$ amplification cycles of $15 \mathrm{~s}$ at $94{ }^{\circ} \mathrm{C}$ and $1 \mathrm{~min}$ at $60{ }^{\circ} \mathrm{C}$ with a final extension of $30 \mathrm{~s}$ at $50{ }^{\circ} \mathrm{C}$. The primers and probe used in this analysis have been described by Gunel et al. (2012).

Ultrapure water and DNA extracted from $T$. gondii ( $\mathrm{RH}$ strain) were included as negative and positive controls, respectively in all PCR reactions (CPCR, Nested PCR and qPCR). To control the course of DNA extraction and check for PCR inhibitors, all samples were assayed using the HGH primer (Accession number: HGH = GenBank: U55206.1 - sense: 5'-GCCTTCCCAACCATTCCCT-3' and antisense: 5'-TCACGGATTTCTG TTGTGTTTC-3'), which amplifies a 400-base-pair fragment of the human growth hormone gene.

\subsection{Statistical analysis}

Statistical analyses used the IBM SPSS software v.23 to determine the Kappa index (KI) and GraphPad Stat Software v. 3.06 was used to determine the sensitivity, specificity, positive predictive value and negative value. Sensitivities and specificities were calculated as: i) percent of sensitivity $=$ ratio of true positives/true positives + false negatives $\times 100$; and $\mathrm{ii}$ ) percent of specificity $=$ ratio of true negatives/true negatives + false positives $\times 100 . P \leq 0.05$ was considered statistically significant.

The strength of the agreement between the 2 serological tests was calculated using the KI. The results are interpreted considering the ranges published by Landis and Koch (1977) where the agreement is considered poor, slight, fair, moderate, substantial and almost perfect when the $\mathrm{KI}$ is $<0,0-0.19,0.2-0.39,0.4-0.59 ; 0.6-0.79$ and $0.8-1.0$, respectively.

\section{Results}

The average age for G1 was 27.6 years [range: $18-41$; standard deviation (SD): 6.0], and for G2 it was 24.0 years (range: $14-42$; SD: 7.0). There was a statistically significant difference between the mean ages of G1 and G2 ( $P=0.0014$; student $t$ test $=3.263$; $d f=145$; $95 \%$ confidence interval: 1428-5816). The KIs for the detection of anti-T gondii IgG and IgM antibodies in G1 were 0.83 and 1.0, respectively, using the ELISA and ELFA serological methods. The agreement was almost perfect between the 2 techniques. The KI for anti-T gondii IgG antibodies of G2 was 1.0 thus the agreement between methods was almost perfect, and for IgM antibodies it was 0.78 , showing that the agreement was substantial between the 2 techniques.

The results of the serological tests for G1 and G2 are shown in Table 1 . Of the 94 samples of G1, only one sample was positive for IgA; this sample was also positive for IgG by ELFA but negative for IgG by ELISA. Of the 53 samples of G2, 30 (56.6\%) were positive for IgA. Of these, 28 (93.3\%) were positive for IgM by ELFA, and 26 (86.7\%) for IgM by ELISA. The avidity test, performed for the 42 (79.2\%) samples that were positive for IgG and IgM, demonstrated high avidity in 31 (73.8\%) samples, intermediate avidity in 4 (9.5\%) samples and low avidity in 7 (16.7\%) samples. Of the 28 samples positive for IgM and IgA by ELISA, 7 (25\%) had low IgG avidity, 3 (10.7\%) had intermediate avidity, and 18 (64.3\%) had high avidity.

Only one (1.1\%) sample in G1 was positive by CPCR (B22/23). In G2, 6 (11.3\%) samples of blood were positive in PCR reactions, of these 3 (5.7\%) were positive by Nested PCR, 4 (7.5\%) by cPCR (B22/B23) and one $(1.9 \%)$ by qPCR. The results of the molecular tests of blood from pregnant women are shown in Table 2.

Of the 50 samples of amniotic fluid that were submitted to CPCR, 29 (58.0\%) were positive and 21 (42.0\%) negative. Of the 29 patients with positive CPCR results for amniotic fluid, 3 were also positive by PCR of blood samples (Nested PCR = 1; $\operatorname{cPCR}(\mathrm{B} 22 / 23)=1$; qPCR = 1), 21 were positive for IgM antibodies by ELISA, 22 for IgM antibodies by ELFA and 19 for IgA antibodies by ELISA. Of the 22 amniotic fluid samples that were positive by CPCR and also positive for IgM antibodies by ELFA and IgG, 6 (27.3\%) had low IgG avidity, 2 (9.1\%) intermediate, and 14 (63.6\%) had high IgG avidity. 
Table 1

Results of serological tests for IgA, IgM and IgG anti-T. gondii antibodies by ELISA (Diasorin, Italy) and ELFA (Biomerieux, France) in pregnant women with (G2) and without (G1) clinical suspicion of toxoplasmosis.

\begin{tabular}{lllllll}
\hline & Positive & \multicolumn{3}{l}{ Negative } & Total \\
\hline G1 $^{*}$ & $\mathrm{n}$ & $\%$ & $\mathrm{n}$ & $\%$ & $\mathrm{n}$ & $\%$ \\
ELISA IgG & 50 & 53.2 & 44 & 46.8 & 94 & 100 \\
ELISA IgM & 0 & 0 & 94 & 100 & 94 & 100 \\
ELISA IgA & 1 & 1.1 & 93 & 98.9 & 94 & 100 \\
ELFA IgG & 58 & 61.7 & 36 & 38.3 & 94 & 100 \\
ELFA IgM & 0 & 0 & 94 & 100 & 94 & 100 \\
G2** & & & & & & \\
ELISA IgG & 53 & 100 & 0 & 0 & 53 & 100 \\
ELISA IgM & 40 & 75.5 & 13 & 24.5 & 53 & 100 \\
ELISA IgA & 30 & 56.6 & 23 & 43.4 & 53 & 100 \\
ELFA IgG & 53 & 100 & 0 & 0 & 53 & 100 \\
ELFA IgM & 42 & 79.2 & 11 & 20.8 & 53 & 100 \\
\hline
\end{tabular}

Note: It was not possible to compare the results by ELISA and ELFA for IgM in G1 or for IgG in G2.

* Statistical analysis of IgG in G1 - ELISA versus ELFA: $P=0.318$; (95\% CI: 0.672-1.104).

** Statistical analysis of IgM in G2 - ELISA versus ELFA: $P=0.816$ (95\% CI: 0.774-1.171).

The sensitivity, specificity, and positive and negative predictive values were calculated for each serological and molecular test separately. The results are shown in Table 3. Table 4 shows the comparison between the avidity with serological and molecular test in clinical samples.

\section{Discussion}

This study compared serological and molecular methods used to identify $T$. gondii infection in pregnant women with and without clinical suspicion of gestational toxoplasmosis in the northwestern region of São Paulo State. The rate of infection of pregnant women, as detected by serological methods, was high in this study, which is in line with other studies conducted in Brazil (Lopes-Mori et al., 2013; Sroka et al., 2010; Vaz et al., 2010) and other countries (Harma et al., 2004; Marquez and Etcheverry, 2009; Pappas et al., 2009; Sanchez-Gutierrez et al., 2003).

Serological methods (ELISA and ELFA), widely used to identify T. gondii infection in Brazil, are highly sensitive and specific (Avelino et al., 2014; Bichara et al., 2012; Câmara et al., 2015; Murata et al., 2016). No statistically significant difference was found between the serological methods in this study. However, 4 samples were discrepant for IgM between the ELFA and ELISA methods, with ELFA having the highest number of positive cases. These samples showed high avidity, which is indicative of chronic infection; 2 were also positive for IgA. The presence of these antibodies, especially IgM in chronic infections, has also been reported by other authors (Bobić et al., 1991; Liesenfeld et al., 1997;

Table 2

Results of molecular tests of blood samples (cPCR (JW62/63), Nested PCR, cPCR (B22/23) and qPCR) in pregnant women with (G2) and without (G1) clinical suspicion of toxoplasmosis.

\begin{tabular}{|c|c|c|c|c|c|c|}
\hline & \multicolumn{2}{|c|}{ Positive } & \multicolumn{2}{|c|}{ Negative } & \multirow{2}{*}{$\frac{\text { Total }}{\mathrm{n}}$} & \multirow[b]{2}{*}{$\%$} \\
\hline & $\mathrm{n}$ & $\%$ & $\mathrm{n}$ & $\%$ & & \\
\hline \multicolumn{7}{|l|}{$\mathrm{G} 1^{*}$} \\
\hline cPCR (JW62/63) & 0 & 0.0 & 94 & 100 & 94 & 100 \\
\hline Nested PCR & 0 & 0.0 & 94 & 100 & 94 & 100 \\
\hline cPCR (B22/23) & 1 & 1.1 & 93 & 98.9 & 94 & 100 \\
\hline qPCR & 0 & 0.0 & 94 & 100 & 94 & 100 \\
\hline \multicolumn{7}{|l|}{$\mathrm{G} 2^{* *}$} \\
\hline cPCR (JW62/63) & 0 & 0.0 & 53 & 100 & 53 & 100 \\
\hline Nested PCR & 3 & 5.7 & 50 & 94.3 & 53 & 100 \\
\hline cPCR (B22/23) & 4 & 7.5 & 49 & 92.5 & 53 & 100 \\
\hline qPCR & 1 & 1.9 & 52 & 98.1 & 53 & 100 \\
\hline
\end{tabular}

* Statistical analysis of G1: cPCR (JW62/63) vs. Nested PCR vs. cPCR (B22/23) vs. qPCR: $P=0.390 ; d f=3 ; \chi^{2}=3.008$

** Statistical analysis of G2: cPCR (JW62/63) vs. Nested PCR vs. CPCR (B22/23) vs. qPCR:

$P=0.158 ; d f=3 ; \chi^{2}=5.196$.
Table 3

Results for sensitivity (S), specificity (E), positive predictive value (PPV) and negative predictive value (NPV) between the serological tests of pregnant women by ELISA (DiaSorin) and ELFA (Biomerieux) and between the molecular tests - cPCR (JW62/63), Nested PCR, cPCR (B22/23) and qPCR.

\begin{tabular}{lllll}
\hline & $\mathrm{S}(\%)$ & $\mathrm{E}(\%)$ & PPV $(\%)$ & NPV $(\%)$ \\
\hline ELISA IgG & 100 & 46.8 & 51.5 & 100 \\
ELISA IgM & 75.5 & 100 & 100 & 87.8 \\
ELFA IgG & 100 & 38.3 & 47.7 & 100 \\
ELFA IgM & 79.2 & 100 & 100 & 89.5 \\
cPCR (JW62/63) & 0.0 & 100 & 0.0 & 63.9 \\
Nested PCR & 5.7 & 100 & 100 & 65.3 \\
cPCR (B22/23) & 7.5 & 98.9 & 80.0 & 65.5 \\
qPCR & 1.9 & 100 & 100 & 64.4 \\
\hline
\end{tabular}

Spalding et al., 2003). IgM antibodies are widely used to identify the disease during acute infections, but they remain detectable for long periods, and thus further tests, such as the IgG avidity test, IgE assay and parasitological tests need to be performed to confirm acute infections (Dhakal et al., 2015).

In this study, ELFA detected more cases positive for IgM antibodies in G2 and more cases with IgG antibodies in G1. This higher positivity may be related to the fact that ELFA is an automated method; for some authors, automated methods are more sensitive and specific (Calderaro et al., 2008; Kasper et al., 2009; Maudry et al., 2009; Murat et al., 2013b; Petersen et al., 2005; Prusa et al., 2010; Rodrigues et al., 2009; Wilson et al., 1997). In this study, ELFA and ELISA had sensitivities of $100 \%$ for IgG, and $79.2 \%$ and $75.5 \%$ for IgM, respectively (Table 3 ). A study conducted by Rodrigues et al. (2009) using 4 serological methods to identify anti-T. gondii infection in neonates, 2 of which were automated (MEIA and ELFA IgM), reported sensitivity and specificity of $60.9 \%$ and $100.0 \%$, respectively against IgM indirect immunofluorescent antibody test (IFAT - 59.6\% and 91.7\%, respectively) and ELISA IgA $(57.1 \%$ and $100.0 \%$, respectively). However, a study by Maudry et al. (2009) that used 6 automated methods to test samples from pregnant women and immunocompromised patients found sensitivity ranging from $89.7 \%$ to $99.4 \%$ and specificity between $99.1 \%$ and $100 \%$.

The better sensitivity displayed by automated methods can improve the diagnosis of $T$. gondii infection in particular during pregnancy, where early diagnosis and treatment of pregnant women have significantly reduced mother-to-child transmission, thereby reducing the risk of serious sequelae in the fetus (Pomares and Montoya, 2016).

The low specificity of IgG antibodies is mainly related to high rates of seroprevalence in the region covered by this study and the life-long permanence of these antibodies in the host, even without the disease, as demonstrated in studies of individuals without clinical symptoms (Fromont et al., 2009; Obaidat et al., 2015; Rodrigues et al., 2015).

The IgA antibody test is not commonly used and its use in the diagnosis of gestational infection has been questioned, even though this test assists in the diagnosis of congenital infection (Faure et al., 1999; Jenum and Stray-Pedersen, 1998; Li et al., 2016; Montoya, 2002; Murat et al., 2013a; Pinon et al., 2001). In this study, IgA positivity in the group of

Table 4

IgG avidity test compared to serological and molecular assays in blood and amniotic fluid (AF) samples.

\begin{tabular}{|c|c|c|c|c|c|}
\hline $\begin{array}{l}\text { High avidity } \\
(n=40)\end{array}$ & Positive & $\begin{array}{l}\text { Intermediate } \\
\text { avidity }(n=4)\end{array}$ & Positive & $\begin{array}{l}\text { Low avidity } \\
(n=7)\end{array}$ & Positive \\
\hline $\begin{array}{l}\text { ELISA and } \\
\text { ELFA IgG }\end{array}$ & 40 & $\begin{array}{l}\text { ELISA and } \\
\text { ELFA IgG }\end{array}$ & 4 & $\begin{array}{l}\text { ELISA and } \\
\text { ELFA IgG }\end{array}$ & 7 \\
\hline ELISA IgM & 29 & ELISA IgM & 4 & ELISA IgM & 7 \\
\hline ELFA IgM & 31 & ELFA IgM & 4 & ELFA IgM & 7 \\
\hline ELISA IgA & 18 & ELISA IgA & 3 & ELISA IgA & 7 \\
\hline cPCR JW62/63 & 0 & cPCR JW62/63 & 0 & cPCR JW62/63 & 0 \\
\hline Nested PCR & 2 & Nested PCR & 1 & Nested PCR & 0 \\
\hline CPCR B22/23 & 3 & cPCR B22/23 & 1 & cPCR B22/23 & 0 \\
\hline qPCR & 0 & qPCR & 0 & qPCR & 1 \\
\hline cPCR (AF) & $20 / 38$ & cPCR (AF) & $2 / 3$ & cPCR (AF) & $6 / 7$ \\
\hline
\end{tabular}


patients with clinical suspicion of toxoplasmosis was high (56.6\%); thus, its use may improve the diagnosis of $T$. gondii infection especially when used with IgM and IgG antibodies (Li et al., 2016; Murata et al., 2016; Pomares and Montoya, 2016; Villard et al., 2016).

Detection of $T$. gondii DNA by molecular methods is quite controversial as there are several techniques and markers to identify the DNA of the parasite, and there is no consensus on which protocol is the best. Moreover, the treatment of pregnant women can modify the results of serological and molecular tests, as has been described by some authors (Lago et al., 2014; Lefevre-Pettazzoni et al., 2007; McLeod, 2014; Okay et al., 2009; Robert-Gangneux and Dardé, 2012).

In this study, there were no statistically significant differences between the molecular methods investigated. In G2, 4 samples (7.5\%) were positive by CPCR using the B22/23 primers. There was no detectable DNA of $T$. gondii using the JW62/63 primer pair; however, after being subjected to a second PCR (nested PCR) 3 (5.7\%) were positive, 2 of which were also positive by cPCR using the B22/23 primers alone. These results could indicate a higher sensitivity of the B22/23 primer pair compared to the JW62/63 primers, similar to the study by Okay et al. (2009) who, on testing amniotic fluid samples, detected 9 (18.0\%) more positive cases in nested PCR using the B22/23 primers than in CPCR (JW62/63).

These discordant findings between molecular methods have also been reported by other studies (Chabbert et al., 2004; Hierl et al., 2004; Nagy et al., 2006; Okay et al., 2009). These authors suggest that disagreements may be related to various factors such as the methods used for genomic DNA extraction, removal of PCR inhibitory factors, the choice of primers and amplification parameters (Chabbert et al., 2004; Nagy et al., 2006; Okay et al., 2009).

Only one sample with low IgG avidity (1.9\%) was positive by qPCR. This finding is significant, because it is expected to detect parasitemia in cases of acute infection (Yamada et al., 2011), as was observed for this sample by low avidity and a positive result by PCR in amniotic fluid.

The results of the PCRs in respect to the avidity test showed that 5 positive samples ( nested PCR $=3$; $\mathrm{CPCR}(\mathrm{B} 22 / 23)=4$ ) had high avidity, and one sample positive by qPCR had low avidity. Given these findings, it is not possible to rule out the possibility of false-positive results by nested PCR and CPCR, as the serological results are suggestive of chronic infection, under which conditions it is not expected to detect parasitemia. Teixeira et al. (2013) described 4 false-positive cases by nested PCR using the B22/23 primers to test amniotic fluid samples. The false-positive results found by CPCR may be related to the fact that carryover associated with post-PCR handling may occur in CPCR and nested PCR with agarose gel electrophoresis and the re-amplification of the PCR product in the nested PCR (Lin et al., 2000; Teixeira et al., 2013). The results of qPCR are understandable as the result of serology suggests an acute infection, which is characterized by periods of parasitemia (Cordeiro et al., 2010). Moreover, qPCR is considered by some authors as a more sensitive technique with low risks of contamination (Homan et al., 2000; Lin et al., 2000; Murat et al., 2013b).

In $\mathrm{G} 1$, only one sample was positive by cPCR using the B22/B23 primer pair. This pregnant woman presented serologically nonreactive IgA and IgM antibodies but she had high concentrations of IgG antibodies by ELISA and ELFA. Cases of chronically infected pregnant women that had reactivation of the disease during pregnancy were reported by Andrade et al. (2010) and Olival et al. (2014), with transmission of the disease to their babies and by Avelar et al. (2015) with a case that progressed to stillbirth during the 34th week of pregnancy. Moreover, de Souza et al. (2015) reported seroconversion in the 17th week of gestation resulting in a spontaneous abortion. The current study only evaluated pregnant women and so serological and molecular monitoring of the mother and the baby would be necessary to confirm the suspicion of gestational and congenital infection. In any case, the possibility of a false-positive result was not ruled out using CPCR, since parasitemia was not identified by other methods.
Of the 50 samples of amniotic fluid subjected to CPCR, 29 (58.0\%) were positive, demonstrating the importance of amniocentesis to assist the diagnosis of fetal infection. When we compared the results of cPCR for amniotic fluid to PCR results for blood samples, we found a statistical difference (cPCR (B22/23): $P<0.0001$; 95\% CI: 0.3647-0.6753; nested PCR: $P<0.0001$; 95\% CI: 0.3895-0.6905 and qPCR: $P<0.0001 ; 95 \% \mathrm{CI}$ : $0.4146-0.7054)$. Ivovic et al. describe several factors that may make the identification of parasite DNA in blood samples difficult, such as the short time the parasite remains in the blood and the action of the immune system that rapidly destroys parasites in the circulation, the small amount of blood drawn compared to the total volume of blood in the human body and PCR inhibition factors present in blood. Moreover, PCR of amniotic fluid samples has shown greater sensitivity compared to other methods such as bioassays and cell cultures (Foulon et al., 1999; Ivovic et al., 2012), thereby proving it to be an important test contributing to the diagnosis of gestational and fetal infections.

In our study, it was not possible to follow up the newborns and establish a relationship of maternal infection with the clinical aspects presented by the neonate in the recommended period, which is a limitation of this study (McLeod et al., 2014; Murat et al., 2013b; Robert-Gangneux and Belaz, 2016; Robert-Gangneux and Dardé, 2012).

In the current study, the differences between the results of the molecular methods highlight the real difficulties still found in the molecular diagnosis of toxoplasmosis using human samples. However, the results of the serological methods used in this study, ELISA and ELFA, agreed for both IgM and IgG antibodies, which is an important finding as these methods are widely used for screening and studies of anti-T. gondii antibodies in different populations of patients such as pregnant women, neonates and immunocompromised patients. The results showed concordance between the serological methods (ELISA and ELFA); however, ELFA identified more positive cases than ELISA. The molecular methods were discrepant with CPCR using the B22/23 primers having the highest sensitivity, but lower specificity compared to the other molecular methods.

\section{Financial Support}

This study was supported by research grants from Fundação de Amparo à Pesquisa do Estado de São Paulo (FAPESP \#2012/07716-9 to LCM; \#2012/07750-2 to FN; \#2013/15879-8 to FHAM; \#2014/017067 to MNF; \#2014/09496-1 to VLPC; \#2014/05302-8 to LC); by the Brazilian Ministry of Science, Technology and Innovation - Conselho Nacional de Desenvolvimento Científico e Tecnológico (PIBIC-CNPq to NSC; to GSS; to MBO), by Fundação de Apoio à Pesquisa e Extensão de São José do Rio Preto (FAPERP to FHAM \#175/2015 and to MNF \#129/ 2015) and by institutional research grant BAP-FAMERP. The opinions, assumptions, and conclusions or recommendations expressed in this material are strictly those of the authors and do not necessarily reflect the views of FAPESP.

\section{Acknowledgments}

We wish to thank Jim Hesson of Academic English Solutions and to David Hewitt for proofreading the English.

\section{References}

Andrade GM, Vasconcelos-Santos DV, Carellos EV, Romanelli RM, Vitor RW, Carneiro AC, et al. Congenital toxoplasmosis from a chronically infected woman with reactivation of retinochoroiditis during pregnancy. J Pediatr 2010;86:85-8. http://dx.doi.org/10. 2223/JPED.1948.

Avelar JB, Rezende HHA, Storchilo HR, Candido RRL, Amaral WN, Avelino MM, et al. Reactivation of toxoplasmosis during the eighth month of pregnancy. Rev Norte Min Enferm 2015;4:57-69.

Avelino MM, Amaral WN, Rodrigues IM, Rassi AR, Gomes MB, Costa TL, et al. Congenital toxoplasmosis and prenatal care state programs. BMC Infect Dis 2014;14:33. http:// dx.doi.org/10.1186/1471-2334-14-33.

Bichara CN, Canto GA, Tostes Cde L, Freitas JJ, Carmo EL, Póvoa MM, et al. Incidence of congenital toxoplasmosis in the City of Belém, state of Pará, northern Brazil, determined 
by a neonatal screening program: preliminary results. Rev Soc Bras Med Trop 2012; 45:122-4. http://dx.doi.org/10.1590/S0037-86822012000100024.

Bittencourt LH, Lopes-Mori FM, Mitsuka-Breganó R, Valentim-Zabott M, Freire RL, Pinto $\mathrm{SB}$, et al. Seroepidemiology of toxoplasmosis in pregnant women since the implementation of the surveillance program of toxoplasmosis acquired in pregnancy and congenital in the western region of Paraná, Brazil. Rev Bras Ginecol Obstet 2012;34: 63-8. http://dx.doi.org/10.1590/S0100-72032012000200004.

Bobić B, Sibalić D, Djurković-Djaković O. High levels of IgM antibodies specific for Toxoplasma gondii in pregnancy 12 years after primary toxoplasma infection. Case report Gynecol Obstet Invest 1991;31:182-4.

Burg JL, Grove CM, Pouletty PJ, Boothroyd JC. Directed and sensitive detection of a pathogenic protozoan, Toxoplasma gondii, by polymerase chain reaction. J Clin Microbiol 1989;27:1787-92.

Calderaro A, Piccolo G, Peruzzi S, Gorrini C, Chezzi C, Dettori G. Evaluation of Toxoplasma gondii immunoglobulin G (IgG) and IgM assays incorporating the newVidiaanalyzer system. Clin Vaccine Immunol 2008;15:1076-9. http://dx.doi.org/10.1128/CVI. 00025-08.

Câmara JT, Silva MG, Castro AM. Prevalence of toxoplasmosis in pregnant women in two reference centers in a city in Northeast Brazil. Rev Bras Ginecol Obstet 2015;37: 64-70. http://dx.doi.org/10.1590/SO100-720320150005115.

Chabbert E, Lachaud L, Crobu L, Bastien P. Comparison of two widely used PCR primer systems for detection of toxoplasma in amniotic fluid, blood, and tissues. J Clin Microbiol 2004:42:1719-22. http://dx.doi.org/10.1128/JCM.42.4.1719-1722.2004.

Colombo FA, Vidal JE, Penalva de Oliveira AC, Hernández AV, Bonasser-Filho F, Nogueira RS, et al. Diagnosis of cerebral toxoplasmosis in AIDS patients in Brazil: importance of molecular and immunological methods using peripheral blood samples. J Clin Microbiol 2005;43:5044-7. http://dx.doi.org/10.1128/JCM.43.10. 5044-5047.2005

Cordeiro CA, Moreira PR, Dutra WO, Young L, Campos WR, Oréfice F, et al. Immunology of the toxoplasmicretinochoroiditis. Arq Bras Oftalmol 2010;73:548-51. http://dx.doi. org/10.1590/S0004-27492010000600018.

de Souza CZ, Marchioro AA, Rafael K, Araújo SM, Falavigna-Guilherme AL. Spontaneous abortion and ocular toxoplasmosis in a couple infected with Toxoplasma gondii. Sci Med 2015;25:21119. http://dx.doi.org/10.15448/1980-6108.2015.3.21119.

Dhakal R, Gajurel K, Pomares C, Talucod J, Press CJ, Montoya JG. Significance of a positive toxoplasma immunoglobulin M test result in the United States. J Clin Microbiol 2015; 53:3601-5. http://dx.doi.org/10.1128/JCM.01663-15.

Dubey JP. The history of Toxoplasma gondii-the first 100 years. J Eukaryot Microbiol 2008; 55:467-75. http://dx.doi.org/10.1111/j.1550-7408.2008.00345.x.

Faure AK, Fricker-Hidalgo H, Pelloux H, Bost-Bru C, Goullier-Fleuret A, Ambroise-Thomas P. Lack of value of specific IgA detection in the postnatal diagnosis of congenital toxoplasmosis. J Clin Lab Anal 1999;13:27-30.

Fochi MM, Baring S, Spegiorin LC, Vaz-Oliani DC, Galão EA, Oliani AH, et al. Prematurity and low birth weight did not correlate with anti-Toxoplasma gondii maternal serum profiles-a Brazilian report. PLoS One 2015;10(7):e0132719. http://dx.doi.org/10. 1371/journal.pone.0132719.

Foulon W, Pinon JM, Stray-Pedersen B, Pollak A, Lappalainen M, Decoster A, et al. Prenatal diagnosis of congenital toxoplasmosis: a multicenter evaluation of different diagnostic parameters. Am J Obstet Gynecol 1999;181:843-7. http://dx.doi.org/10.1016/ S0002-9378(99)70311-X.

Fromont EG, Riche B, Rabilloud M. Toxoplasma seroprevalence in a rural population in France: detection of a household effect. BMC Infect Dis 2009;9:76. http://dx.doi.org/ 10.1186/1471-2334-9-76.

Gonçalves MA, Mattos Cde C, Spegiorin LC, Oliani DC, Oliani AH, Mattos LC Seropositivity rates for toxoplasmosis, rubella, syphilis, cytomegalovirus, hepatitis and HIV among pregnant women receiving care at a public health service, São Paulo state, Brazil. Braz J Infect Dis 2010;14:601-5. http://dx.doi.org/10.1590/ S1413-86702010000600009.

Gontijo da Silva M, ClareVinaud M, de Castro AM. Prevalence of toxoplasmosis in pregnant women and vertical transmission of Toxoplasma gondii in patients from basic units of health from Gurupi, Tocantins, Brazil, from 2012 to 2014. PLoS One 2015; 10(11):e0141700. http://dx.doi.org/10.1371/journal.pone.0141700.

Gunel T, Kalelioglu I, Ermis H, Has R, Aydinli K. Large-scale pre-diagnosis of Toxoplasma gondii DNA genotyping by real-time PCR on amniotic fluid. Biotechnol Biotechnol Equip 2012;26:2913-5. http://dx.doi.org/10.5504/BBEQ.2011.0106.

Harma M, Harma M, Gungen N, Demir N. Toxoplasmosis in pregnant women in Sanliurfa, southeastern Anatolia City, Turkey. J Egypt Soc Parasitol 2004;34:519-25.

Hierl T, Reischl U, Lang P, Hebart H, Stark M, Kyme P, et al. Preliminary evaluation of one conventional nested and two real-time PCR assays for the detection of Toxoplasma gondii in immunocompromised patients. J Med Microbiol 2004;53:629-32. http:// dx.doi.org/10.1099/jmm.0.45566-0.

Homan WL, Vercammen M, de Braekeleer J, Verschueren H. Identification of a 200- to 300 -fold repetitive 529 base-pair DNA fragment in Toxoplasma gondii, and its use for diagnostic and quantitative PCR. Int J Parasitol 2000;30:69-75. http://dx.doi.org/ 10.1016/S0020-7519(99)00170-8

Ivovic V, Vujanic M, Zivkovic T, Klun I, Djurkovic-Djakovic O. Molecular detection and genotyping of Toxoplasma gondii from clinical samples. In Toxoplasmosis-Recent Advances. InTech 2012. http://dx.doi.org/10.5772/50830.

Jenum PA, Stray-Pedersen B. Development of specific immunoglobulins G, M, and a following primary Toxoplasma gondii infection in pregnant women. J Clin Microbiol 1998;36:2907-13.

Kasper DC, Prusa AR, Hayde M, Gerstl N, Pollak A, Herkner KR, et al. Evaluation of the VitrosECiQ immunodiagnostic system for detection of anti-toxoplasma immunoglobulin $\mathrm{G}$ and immunoglobulin $\mathrm{M}$ antibodies for confirmatory testing for acute Toxoplasma gondii infection in pregnant women. J Clin Microbiol 2009;47:164-7. http://dx. doi.org/10.1128/JCM.01435-08.
Lago EG, Oliveira AP, Bender AL. Presence and duration of anti-Toxoplasma gondii immunoglobulin M in infants with congenital toxoplasmosis. J Pediatr 2014;90:363-9. http://dx.doi.org/10.1016/j.jped.2013.12.006.

Landis JR, Koch GG. The measurement of observer agreement for categorical data. Biometrics 1977;33:159-74http://www.jstor.org/stable/2529310.

Lefevre-Pettazzoni M, Bissery A, Wallon M, Cozon G, Peyron F, Rabilloud M. Impact of spiramycin treatment and gestational age on maturation of Toxoplasma gondii immunoglobulin G avidity in pregnant women. Clin Vaccine Immunol 2007;14:239-43. http://dx.doi.org/10.1128/CVI.00311-06.

Li X, Pomares C, Gonfrier G, Koh B, Zhu S, Gong M, et al. Multiplexed anti-toxoplasma IgG, IgM, and IgA assay on Plasmonic gold chips: towards making mass screening possible with dye test precision. J Clin Microbiol 2016;54:1726-33. http://dx.doi.org/10.1128/ JCM.03371-15.

Liesenfeld O, Press C, Montoya JG, Gill R, Isaac-Renton JL, Hedman K, et al. False-positive results in immunoglobulin M (IgM) toxoplasma antibody tests and importance of confirmatory testing: the Platelia Toxo IgM test. J Clin Microbiol 1997;35:174-8.

Lin MH, Chen TC, Kuo TT, Tseng CC, Tseng CP. Real-time PCR for quantitative detection of Toxoplasma gondii. J Clin Microbiol 2000;38:4121-5.

Lopes-Mori FM, Mitsuka-Breganó R, Bittencourt LH, Dias RC, Gonçalves DD, Capobiango JD, et al. Gestational toxoplasmosis in Paraná state, Brazil: prevalence of IgG antibodies and associated risk factors. Braz J Infect Dis 2013;17:405-9. http://dx.doi.org/10. 1016/j.bjid.2012.12.003.

Marquez MDLA, Etcheverry IS. Seroprevalence of toxoplasmosis in pregnant women in La Plata area. Acta Bioquim Clin Latinoam 2009;37:413-5.

Mattos CC, Meira CS, Ferreira AI, Frederico FB, Hiramoto RM, Jr GC, et al. Contribution of laboratory methods in diagnosing clinically suspected ocular toxoplasmosis in Brazilian patients. Diagn Microbiol Infect Dis 2011b;70:362-6. http://dx.doi.org/10. 1016/j.diagmicrobio.2011.02.002.

Mattos C de C, Spegiorin LC, Meira C da S, Silva T da C, Ferreira AI, Nakashima F, et al. AntiToxoplasma gondii antibodies in pregnant women and their newborn infants in the region of São José do Rio Preto, São Paulo, Brazil. Sao Paulo Med J 2011a;129: 261-6. http://dx.doi.org/10.1590/S1516-31802011000400010.

Maudry A, Chene G, Chatelain R, Patural H, Bellete B, Tisseur B, et al. Bicentric evaluation of six anti-toxoplasma immunoglobulin G (IgG) automated immunoassays and comparison to the Toxo II IgG western blot. Clin Vaccine Immunol 2009;16:1322-6. http://dx.doi.org/10.1128/CVI.00128-09.

McLeod R. Utility and limitations of T. gondii-specific IgM serum antibodies in the diagnosis of congenital toxoplasmosis in Porto Alegre. J Pediatr (Rio J) 2014;90:329-31. http://dx.doi.org/10.1016/j.jped.2014.04.001.

McLeod R, Boyer KM, Lee D, Mui E, Wroblewski K, Karrison T, et al. Prematurity and severity are associated with Toxoplasma gondii alleles (NCCCTS, 1981-2009). Clin Infect Dis 2012;54:1595-605. http://dx.doi.org/10.1093/cid/cis258.

McLeod R, Lykins J, Noble AG, Rabiah P, Swisher CN, Heydemann PT, et al. Management of Congenital Toxoplasmosis. Curr Pediatr Rep 2014;2:166-94. http://dx.doi.org/10. 1007/s40124-014-0055-7.

Montoya JG. Laboratory diagnosis of Toxoplasma gondii infection and toxoplasmosis. J Infect Dis 2002;185:S73-82. http://dx.doi.org/10.1086/338827.

Moura FL, Amendoeira MR, Bastos OM, Mattos DP, Fonseca AB, Nicolau JL, et al. Prevalence and risk factors for Toxoplasma gondii infection among pregnant and postpartum women attended at public healthcare facilities in the City of Niterói, state of Rio de Janeiro, Brazil. Rev Soc Bras Med Trop 2013;46:200-7. http://dx.doi.org/10. 1590/0037-8682-1613-2013.

Murat JB, Dard C, Fricker Hidalgo H, Dardé ML, Brenier-Pinchart MP, Pelloux H. Comparison of the Vidas system and two recent fully automated assays for diagnosis and follow-up of toxoplasmosis in pregnant women and newborns. Clin Vaccine Immunol 2013b;20:1203-12. http://dx.doi.org/10.1128/CVI.00089-13.

Murat JB, Hidalgo HF, Brenier-Pinchart MP, Pelloux H. Human toxoplasmosis: which biological diagnostic tests are best suited to which clinical situations? Expert Rev Anti Infect Ther 2013a;11:943-56. http://dx.doi.org/10.1586/14787210.2013. 825441.

Murata FHA, Ferreira MN, Camargo NS, Santos GS, Spegiorin LCJF, Silveira-Carvalho AP, et al. Frequency of the anti-Toxoplasma gondii antibodies class IgA, IgM and IgG in high risk pregnancy women, Brazil. Rev Soc Bras Med Trop 2016. http://dx.doi.org/ 10.1590/0037-8682-0046-2016

Nagy B, Bán Z, Beke A, Nagy GR, Lázár L, Papp C, et al. Detection of Toxoplasma gondii from amniotic fluid, a comparison of four different molecular biological methods. Clin Chim Acta 2006;368:131-7. http://dx.doi.org/10.1016/j.cca.2005.12.023.

Obaidat MM, Al-Sheyab NA, Bani Salman AE, Lafi SQ. Seroepidemiology and risk factors of Toxoplasma gondii infection in undergraduate university female students in Jordan. Epidemiol Infect 2015;143:1898-903. http://dx.doi.org/10.1017/S0950268814003604.

Okay TS, Yamamoto L, Oliveira LC, Manuli ER, Andrade Junior HF, Del Negro GM. Significant performance variation among PCR systems in diagnosing congenital toxoplasmosis in São Paulo, Brazil: analysis of 467 amniotic fluid samples. Clinics 2009;64: 171-6. http://dx.doi.org/10.1590/S1807-59322009000300004.

Olival V, Correia A, Bello A, Cabugueira A, Nunes MJ. Ocular toxoplasmosis reactivation during pregnancy. Acta Obstet Ginecol Port 2014;8:82-3.

Pappas G, Roussos N, Falagas ME. Toxoplasmosis snapshots: global status of Toxoplasma gondiiseroprevalence and implications for pregnancy and congenital toxoplasmosis. Int J Parasitol 2009;39:1385-94. http://dx.doi.org/10.1016/j.ijpara.2009.04.003.

Petersen E, Borobio MV, Guy E, Liesenfeld O, Meroni V, Naessens A, et al. European multicenter study of the LIAISON automated diagnostic system for determination of Toxoplasma gondii-specific immunoglobulin G (IgG) and IgM and the IgG avidity index. J Clin Microbiol 2005;43:1570-4. http://dx.doi.org/10.1128/JCM.43.4.15701574.2005.

Pinon JM, Dumon H, Chemla C, Franck J, Petersen E, Lebech M, et al. Strategy for diagnosis of congenital toxoplasmosis: evaluation of methods comparing mothers and 
newborns and standard methods for postnatal detection of immunoglobulin G, M, and a antibodies. J Clin Microbiol 2001;39:2267-71. http://dx.doi.org/10.1128/JCM. 39.6.2267-2271.2001.

Pomares C, Montoya JG. Laboratory diagnosis of congenital toxoplasmosis. J Clin Microbiol 2016. http://dx.doi.org/10.1128/JCM.00487-16. [pii: JCM.00487-16, Epub ahead of print].

Porto AM, Amorim MM, Coelho IC, Santos LC. Serologic profile of toxoplasmosis in pregnant women attended at a teaching-hospital in Recife. Rev Assoc Med Bras 2008;54: 242-8. http://dx.doi.org/10.1590/S0104-42302008000300018.

Prusa AR, Hayde M, Unterasinger L, Pollak A, Herkner KR, Kasper DC. Evaluation of the Roche ElecsysToxo IgG and IgM electrochemiluminescence immunoassay for the detection of gestational toxoplasma infection. Diagn Microbiol Infect Dis 2010;68: 352-7. http://dx.doi.org/10.1016/j.diagmicrobio.2010.07.011.

Rebouças EC, dos Santos EL, do Carmo ML, Cavalcante Z, Favali C. Seroprevalence of toxoplasma infection among pregnant women in Bahia, Brazil. Trans R Soc Trop Med Hyg 2011;105:670-1. http://dx.doi.org/10.1016/j.trstmh.2011.07.006.

Robert-Gangneux F, Belaz S. Molecular diagnosis of toxoplasmosis in immunocompromised patients. Curr Opin Infect Dis 2016;29:330-9. http://dx.doi.org/10.1097/QCO. 0000000000000275.

Robert-Gangneux F, Dardé ML. Epidemiology of and diagnostic strategies for toxoplasmosis. Clin Microbiol Rev 2012;25:264-96. http://dx.doi.org/10.1128/CMR.05013-11.

Rodrigues IM, Castro AM, Gomes MB, Amaral WN, Avelino MM. Congenital toxoplasmosis: evaluation of serological methods for the detection of anti-Toxoplasma gondi IgM and IgA antibodies. Mem Inst Oswaldo Cruz 2009;104:434-40. http://dx.doi. org/10.1590/S0074-02762009000300006.

Rodrigues JP, Frei F, Navarro IT, Silva LP, Marcelino MY, de Andrade-Junior HF, et at. Seroepidemiological analysis of toxoplasmosis in college students. J Venom Anim Toxins Incl Trop Dis 2015;21:1. http://dx.doi.org/10.1186/1678-9199-21-1.

Sanchez-Gutierrez A, Martin-Hernandez I, Garcia-Izquierdo SM. Estudio de reactividad a Toxoplasma gondiienembarazadas de lasprovinciasCiudad de la Habana y Pinar del
Rio, Cuba. Bioquimia 2003;28:3-8. [http://www.medigraphic.com/pdfs/bioquimia/ bq-2003/bq032b.pdf].

Spalding SM, Amendoeira MR, Klein CH, Ribeiro LC. Serological screening and toxoplasmosis exposure factors among pregnant women in south of Brazil. Rev Soc Bras Med Trop 2005;38:173-7. http://dx.doi.org/10.1590/S0037-86822005000200009.

Spalding SM, Amendoeira MR, Ribeiro LC, Silveira C, Garcia AP, Camillo-Coura L. Prospective study of pregnants and babies with risk of congenital toxoplasmosis in municipal district of Rio Grande do Sul. Rev Soc Bras Med Trop 2003;36:483-91. http://dx.doi. org/10.1590/S0037-86822003000400009.

Sroka S, Bartelheimer N, Winter A, Heukelbach J, Ariza L, Ribeiro H, et al. Prevalence and risk factors of toxoplasmosis among pregnant women in Fortaleza, northeastern Brazil. Am J Trop Med Hyg 2010;83:528-33. http://dx.doi.org/10.4269/aitmh.2010.10-0082.

Teixeira LE, Kanunfre KA, Shimokawa PT, Targa LS, Rodrigues JC, Domingues W, et al. The performance of four molecular methods for the laboratory diagnosis of congenital toxoplasmosis in amniotic fluid samples. Rev Soc Bras Med Trop 2013;46:584-8. http://dx.doi.org/10.1590/0037-8682-0095-2013.

Vaz RS, Thomaz-Soccol V, Sumikawa E, Guimarães AT. Serological prevalence of Toxoplasma gondii antibodies in pregnant women from southern Brazil. Parasitol Res 2010; 106:661-5. http://dx.doi.org/10.1007/s00436-009-1716-2.

Villard O, Cimon B, L'Ollivier C, Fricker-Hidalgo H, Godineau N, Houze S, et al. Serological diagnosis of toxoplasma gondii infection: recommendations from the French National Reference Center for toxoplasmosis. Diagn Microbiol Infect Dis 2016;84:22-33. http://dx.doi.org/10.1016/j.diagmicrobio.2015.09.009.

Wilson M, Remington JS, Clavet C, Varney G, Press C, Ware D. Evaluation of six commercial kits for detection of human immunoglobulin $\mathrm{M}$ antibodies to Toxoplasma gondii. The FDA toxoplasmosis ad hoc working group. J Clin Microbiol 1997;35:3112-5.

Yamada H, Nishikawa A, Yamamoto T, Mizue Y, Yamada T, Morizane M, et al. Prospective study of congenital toxoplasmosis screening with use of $\operatorname{IgG}$ avidity and multiplex nested PCR methods. J Clin Microbiol 2011;49:2552-6. http://dx.doi.org/10.1128/ JCM.02092-10. 